\title{
Factors associated with first-line antiretroviral treatment failure in adult HIV- positive patients: a case-control study from Ethiopia
}

\author{
Yihienew Mequanint Bezabih ${ }^{1,2^{*}}$ (D) Fekadu Beyene ${ }^{1}$ and Woldesellassie M. Bezabhe ${ }^{3}$
}

\begin{abstract}
Background: Treatment failure has become a significant challenge in patients taking antiretroviral therapy (ART). The aim of the present study was to identify risk factors for first-line ART failure among patients attending clinical follow-up.

Methods: A 1:2 matched case-control study (by age, sex, and treatment duration since initiated on ART) was conducted from June 2015 to July 2017 on adult patients (aged $\geq 15$ years) who were on ART for at least 6 months. Cases were selected from patients who were switched to second-line ART after first-line ART failure (viral load $\geq 1000$ copies $/ \mathrm{mL}$ ). Controls were randomly selected from patients on first-line ART with viral load $<50$ copies $/ \mathrm{mL}$. Data were collected using an interview questionnaire, reviewing chart and electronic health records and laboratory tests. Multivariate logistic regression analysis was performed to identify risk factors for treatment failure.

Results: Of the 273 patients who participated in this study, 55\% were males. Ninety-one cases were compared with 182 controls. The median age of participants was 40 years and the median duration of treatment since initiated on ART was 69 months. Independent risk factors associated with first-line antiretroviral treatment failure were discontinuation of ART (adjusted odds ratio $(A O R)=9.8,95 \%$ confidence interval $(C \mathrm{Cl}): 4.0-23.8$ ), baseline CD4 lymphocyte count $\leq 50 \mathrm{cell} / \mathrm{s} / \mathrm{mm}^{3}$ $(A O R=3.8,95 \% \mathrm{Cl}: 1.5-9.6)$ and persistent diarrhea (AOR $=4.4,95 \% \mathrm{Cl}: 1.5-13.2)$. The risk of ART failure was high and comparable whether the duration of ART discontinuation was greater or less than 1 month (crude odds ratio $(C O R)=6.3$ and 8.5 respectively, $p$-value $<0.001$ ). Frequent eating of a diet containing wheat or barley ( $\mathrm{AOR}=2.3,95 \% \mathrm{Cl}: 0.9-5.4$ ) showed a trend to be a risk factor for first-line ART failure ( $p$-value $=0.064$ ).

Conclusions: Our findings underscore the importance of avoiding ART discontinuation of any duration, early initiation of ART and diarrhea management to prevent first-line ART failure.
\end{abstract}

Keywords: Virologic failure, Antiretroviral, Case-control, HIV, AIDS, Ethiopia

\section{Background}

Worldwide Human Immunodeficiency Virus (HIV)/Acquired Immune Deficiency Syndrome (AIDS) is a major public health issue. In 2017, over 36.9 million people were living with HIV/AIDS. The most affected continent, Africa, had 25.7 million (70\%) people with HIV/

\footnotetext{
*Correspondence: myihienew@gmail.com; yihienew.bezabih@oniris-nantes.fr ${ }^{1}$ College of Health Sciences, Arsi University, Arsi, Ethiopia

${ }^{2}$ ONIRIS: The Nantes-Atlantic National College of Veterinary Medicine, Nantes, France

Full list of author information is available at the end of the article
}

AIDS. In Ethiopia, about 710, 000 people were living with the disease as of 2017 [1]. The global antiretroviral therapy (ART) coverage increased progressively from $7 \%$ in 2005 to $59 \%$ in 2017 [2, 3]. The estimated coverages in 2017 were 60 and 59\% for Africa and Ethiopia, respectively [1].

Because of this extensive ART scale-up, treatment failure has become an emerging problem $[4,5]$. The prevalence of first-line ART failure differs significantly across countries depending on the criteria (clinical, immunological or virologic) used for its diagnosis. The viral load

(c) The Author(s). 2019 Open Access This article is distributed under the terms of the Creative Commons Attribution 4.0 International License (http://creativecommons.org/licenses/by/4.0/), which permits unrestricted use, distribution, and 
cut-off points to diagnose treatment failure also vary in different countries. The first-line ART virologic failure rate in Africa was 7.1 (95\% CI: 5.1-9.1) per 100 patientyears of follow-up [6]. In Ethiopia, studies reported virologic failure rates ranging from 5.3 to $19 \%$ [7-9], and the percentage of patients switched to second-line ART was $1.5 \%$ in 2013 [10]. Switching to second-line ART means that patients are receiving more toxic medications. As a result, patients become less adherent, and AIDS progression will be more rapid, both of which make patient monitoring expensive [11-14].

Previous studies identified that suboptimal adherence, adverse drug reactions $[15,16]$, higher pretreatment (baseline) HIV viral load level, baseline World Health Organization (WHO) AIDS stage 3 or 4, CD4 lymphocyte count $<50$ cells $/ \mathrm{mm}^{3}$, low body mass index (BMI), drug interactions and dyspepsia as an important risk factors for treatment failure [1722]. A study with a clear distinction between participants with and without ART failure remains important to identify predictors of treatment failure. To our knowledge, most studies from Ethiopia used clinical and immunologic criteria to assess factors that influence treatment failure. As immunologic and clinical criteria have low sensitivity and specificity to identify true ART failure [23], it could be difficult to identify risk factors based on these two criteria alone. Therefore, this study aimed to investigate risk factors for first-line antiretroviral failure using the virologic (plasma viral load) criteria.

\section{Methods}

\section{Study setting}

This study was carried out at the ART follow-up clinic of Asella Hospital, Ethiopia. The hospital gives clinical service to a total population of about 3.5 million people. There were 3238 patients with HIV/AIDS (including those from the surrounding rural areas and nearby towns) who had an ART follow-up in the hospital of which 102 (3.2\%) patients were on second-line ART.

\section{Study design and participants}

A 1:2 matched case-control study (by age, sex and treatment duration since initiated on ART) was conducted between June 2015 to July 2017 (study period). All adult HIV-positive patients (aged $\geq 15$ years) who were on ART for at least 6 months and whose baseline CD4 lymphocyte count and WHO HIV stage details available using the ART electronic health record of Asella Hospital were our target population. This data ranges from January 2005 to May 2017, and only patients not died and had an active follow-up at the time of the study were included. Ninety-one patients who were receiving second-line ART were selected as cases. Treatment failure status for cases was confirmed by two viral load tests (viral load $\geq 1000$ copies $/ \mathrm{mL}$ ), performed 3 months apart as per national guideline, before a change of ART regimen. Controls were 182 patients with undetectable viral load (less than 50 copies $/ \mathrm{mL}$ ) who were taking first-line ART for at least 6 months. Details of the selection process are described below (Fig. 1).

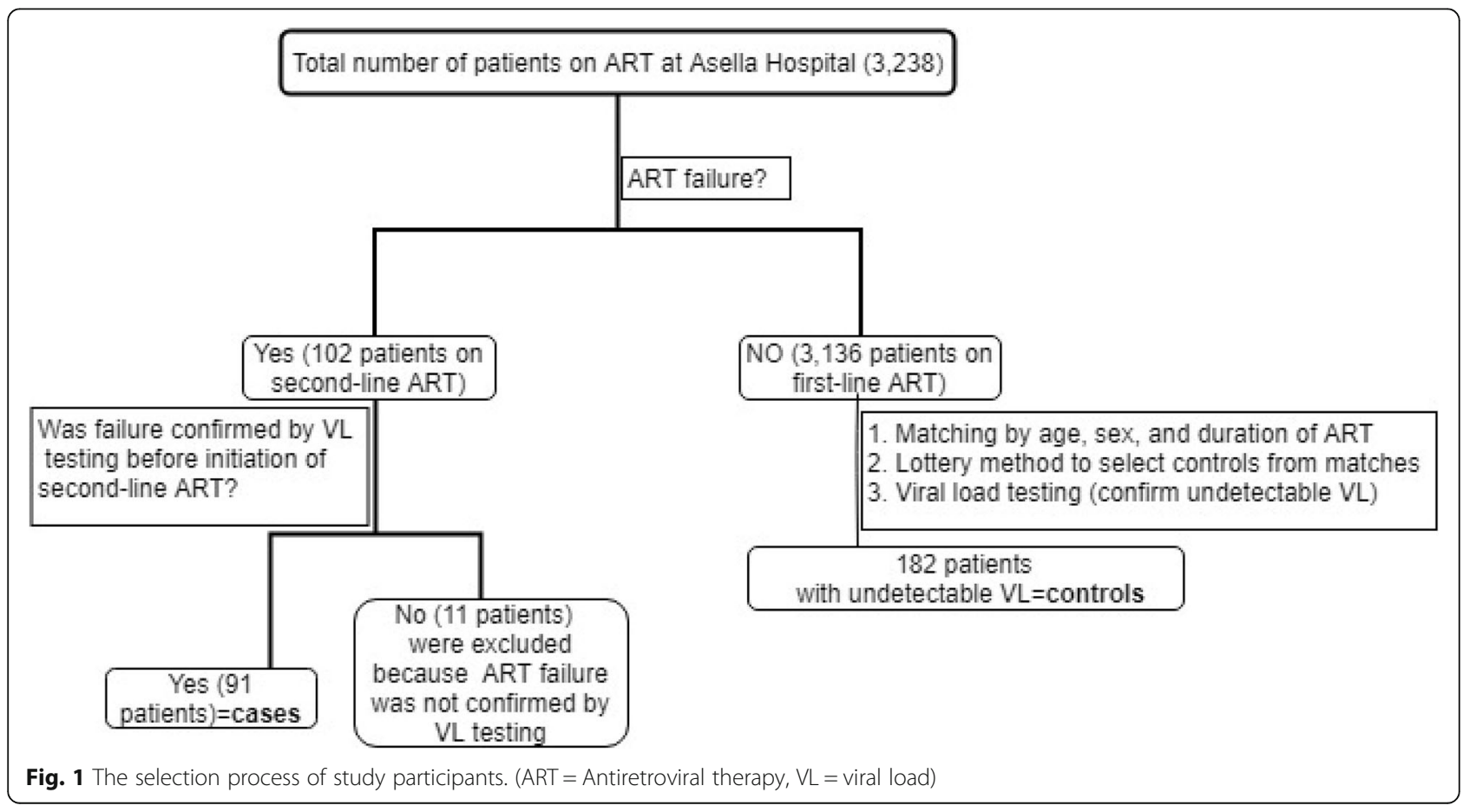


For each case, two controls were selected using a lottery method after being matched by age, sex, and duration on ART. We used the following technique for selecting controls for each case. For example, for a case who commenced ART in June 2005, we used an electronic ART database to find two controls who were also initiated on ART in June 2005 with similar gender and within \pm 5 years of age of the case.

\section{Variables and measures}

Sociodemographic and clinical characteristics of participants were assessed for their possible association with the outcome variable (ART failure) (Table 1). The variables measured before ART initiation were baseline CD4 lymphocyte count and WHO HIV stage, whereas all the other variables were retrospectively measured during patient follow-up after ART was started.

Duration on ART was defined as the total time (in months) a patient was on ART since initial enrolment into ART care excluding the period of interruptions. Discontinuation of ART for a patient currently on ART was defined as having a history of complete stoppage of ART medications for any duration; whereas missed ART follow-up meant that a patient missed a drug refill date. The ART regimen for cases was their first-line ART regimen, not their current second-line regimen.

Repeated or persistent diarrhea was defined as $\geq 2$ episodes of diarrhea or a single episode lasting more than 2 weeks, respectively. We used the term psychiatric illness in patients who were diagnosed with a disorder listed in the Diagnostic and Statistical Manual of Mental Disorders IV [24]. Tuberculosis (TB) co-infection was defined as an active TB disease requiring a curative therapy with anti-TB medications. Alcohol use was defined as the use of alcoholic beverages in any amount. A main-diet constitutes the usual sum of food consumed by participants in a stable manner for years. Poor drug absorption was assumed to be present in those patients who experienced diarrhea (repeated or persistent) and frequently eat wheat or barely. For variables measuring co-existing chronic infections, we presumed that these diseases were either acquired during a similar high-risk behavior that led to the acquisition of HIV itself (hepatitis $B$ virus (HBV), hepatitis $\mathrm{C}$ virus (HCV), and syphilis) or acquired early in life (HBV and Helicobacter pylori (H. pylori) infection).

\section{Data collection tool and procedure}

The data collection tools were interview-questionnaire, electronic ART database, patient chart review and virologic test for selection of controls. In addition, other laboratory tests were also performed to detect chronic carrier state for infections, including $\mathrm{HBV}, \mathrm{HCV}, H$. pylori and Venereal disease research laboratory (VDRL) tests for both cases and controls.

The questionnaire was first developed in English and translated into local languages, Oromiffa and Amharic, and cross-checked for consistency. It was piloted, modified and validated. Training was provided for the study team before the start of the project. The research team included the three investigators, two registered nurses who assisted patients to complete the questionnaire, five laboratory technicians and an IT professional to record all the observations into Epi-info software daily. The investigators continuously monitored the data collection process throughout the study. Data completeness was regularly checked, and any missing data were obtained on the subsequent follow-up of patients.

\section{Data processing and analysis}

Data from Epi-Info was exported to SPSS statistics version 23.0. Descriptive statistics were used to present socio-demographic and clinical characteristics. Bivariate logistic regression analysis was carried out, and independent variables with $p$-values of $\leq 0.2$ were included in multivariate logistic regression analysis. Prior to the multivariate analysis, multicollinearity diagnostics was performed, and there were no significant interactions between independent variables. Adjusted odds ratios (AOR) with 95\% confidence intervals (CIs) were used as an effect measure. A $p$-value of equal or less than 0.05 was considered as significant. The matching factors (age, sex and duration of ART) were included in the adjusted analysis.

\section{Ethics approval}

Ethical approval was obtained from the Arsi University College of Health Sciences Ethics Review Board. Informed consent was obtained from study participants. Information gathered from respondents was treated confidentially, and the norm of the community was considered and respected in the process of data collection. Patients with abnormal findings were referred to the treating physician and were provided with the appropriate care.

\section{Results}

Socio-demographic characteristics of participants

Of all 273 study participants, 55\% were males. The median age of the participants was 40 years. The median duration of treatment was 69 months. Most of the participants were Orthodox Christian 187 (69\%), married 160 (59\%), and literate 234 (86\%). Approximately threequarters of patients were living in the urban area, and 267 (98\%) were employed (Table 1). 
Table 1 Socio-demographic and baseline clinical characteristic of adult HIV-positive patients, Southeast Ethiopia, 2015-2017

\begin{tabular}{|c|c|c|c|}
\hline Variables & $\begin{array}{l}\text { Total } \\
(N=273)\end{array}$ & $\begin{array}{l}\text { Patients with ART failure (Cases) } \\
(N=91)\end{array}$ & $\begin{array}{l}\text { Patients without ART failure (Controls) } \\
(N=182)\end{array}$ \\
\hline Gender-male & 149 (55\%) & $52(19 \%)$ & $97(36 \%)$ \\
\hline Median age in years (IQR) & $40(11)$ & $39(10)$ & $40(12)$ \\
\hline \multicolumn{4}{|l|}{ Religion } \\
\hline Orthodox Christian & 187 (69\%) & $62(23 \%)$ & $125(46 \%)$ \\
\hline Muslim & $160(21 \%)$ & $20(7 \%)$ & $37(14 \%)$ \\
\hline Protestant & $27(10 \%)$ & $9(3 \%)$ & $18(7 \%)$ \\
\hline Others & $2(1 \%)$ & $0(0 \%)$ & $2(1 \%)$ \\
\hline \multicolumn{4}{|l|}{ Marital status } \\
\hline Married & 160 (59\%) & $47(17 \%)$ & $113(41 \%)$ \\
\hline Not married & $113(41 \%)$ & $44(16 \%)$ & $69(25 \%)$ \\
\hline \multicolumn{4}{|l|}{ Family size } \\
\hline$\leq 5$ family members & 217 (80\%) & $76(28 \%)$ & $141(52 \%)$ \\
\hline$>5$ family members & $54(20 \%)$ & $13(5 \%)$ & $41(15 \%)$ \\
\hline \multicolumn{4}{|l|}{ Educational status } \\
\hline Illiterate & 39 (14\%) & $12(4 \%)$ & $27(10 \%)$ \\
\hline Literate & $234(86 \%)$ & 79 (29\%) & $155(57 \%)$ \\
\hline \multicolumn{4}{|l|}{ Employment } \\
\hline Employed & 267 (98\%) & 87 (32\%) & $180(66 \%)$ \\
\hline Unemployed & $6(2 \%)$ & $4(1 \%)$ & $2(1 \%)$ \\
\hline \multicolumn{4}{|l|}{ Residence area } \\
\hline Rural & $67(25 \%)$ & $28(10 \%)$ & $39(14 \%)$ \\
\hline Urban & $206(76 \%)$ & $63(23 \%)$ & $143(52 \%)$ \\
\hline \multicolumn{4}{|l|}{ Khat** chewing } \\
\hline Yes & $10(4 \%)$ & $4(4 \%)$ & $6(3 \%)$ \\
\hline No & $263(96 \%)$ & $87(96 \%)$ & $176(97 \%)$ \\
\hline \multicolumn{4}{|l|}{ Alcohol use } \\
\hline Yes & $7(3 \%)$ & $1(1 \%)$ & $6(3 \%)$ \\
\hline No & $266(97 \%)$ & $90(99 \%)$ & $176(97 \%)$ \\
\hline \multicolumn{4}{|l|}{ Smoke cigarettes } \\
\hline Yes & $6(2 \%)$ & $3(3 \%)$ & $3(2 \%)$ \\
\hline No & $267(98 \%)$ & $88(97 \%)$ & $179(98 \%)$ \\
\hline \multicolumn{4}{|l|}{ Main diet } \\
\hline Wheat or barley & $40(15 \%)$ & $18(20 \%)$ & $22(12 \%)$ \\
\hline Teff & $165(60 \%)$ & $54(60 \%)$ & $111(61 \%)$ \\
\hline Others & $68(25 \%)$ & 19 (20\%) & $49(27 \%)$ \\
\hline \multicolumn{4}{|l|}{ Poor drug absorption } \\
\hline Main diet wheat or barley with diarrhea & $3(1 \%)$ & $3(3 \%)$ & $0(0 \%)$ \\
\hline Main diet wheat or barley without diarrhea & $37(14 \%)$ & $15(16 \%)$ & $22(12 \%)$ \\
\hline Duration on ART median in months (IQR) & $69(41)$ & $64(39)$ & $72(36)$ \\
\hline \multicolumn{4}{|l|}{ Baseline CD4 lymphocyte count } \\
\hline$<50$ cells $/ \mathrm{mm}^{3}$ & $33(12 \%)$ & $20(22 \%)$ & $13(7 \%)$ \\
\hline$\geq 50$ cells $/ \mathrm{mm}^{3}$ & $240(88 \%)$ & $71(78 \%)$ & $169(93 \%)$ \\
\hline
\end{tabular}

Baseline WHO HIV stage 
Table 1 Socio-demographic and baseline clinical characteristic of adult HIV-positive patients, Southeast Ethiopia, 2015-2017 (Continued)

\begin{tabular}{|c|c|c|c|}
\hline Variables & $\begin{array}{l}\text { Total } \\
(N=273)\end{array}$ & $\begin{array}{l}\text { Patients with ART failure (Cases) } \\
(N=91)\end{array}$ & $\begin{array}{l}\text { Patients without ART failure (Controls) } \\
(N=182)\end{array}$ \\
\hline Stage 1 & $26(10 \%)$ & $8(9 \%)$ & $18(10 \%)$ \\
\hline Stage 2 & $93(34 \%)$ & $22(24 \%)$ & 71 (39\%) \\
\hline Stage 3 & $140(51 \%)$ & $52(57 \%)$ & $88(48 \%)$ \\
\hline Stage 4 & $14(5 \%)$ & $9(10 \%)$ & $5(3 \%)$ \\
\hline \multicolumn{4}{|l|}{ ART regimen } \\
\hline AZT based & $130(48 \%)$ & $57(63 \%)$ & $96(53 \%)$ \\
\hline TDF based & $143(52 \%)$ & $34(37 \%)$ & $86(47 \%)$ \\
\hline \multicolumn{4}{|l|}{ TB treatment while taking ART } \\
\hline Never & $231(85 \%)$ & $58(64 \%)$ & $173(95 \%)$ \\
\hline Once & $33(12 \%)$ & $26(28 \%)$ & $7(4 \%)$ \\
\hline Two times & $8(3 \%)$ & $6(7 \%)$ & $2(1 \%)$ \\
\hline Three or more & $1(0 \%)$ & $1(1 \%)$ & $0(0 \%)$ \\
\hline Never discontinued ART & $212(78 \%)$ & 49 (54\%) & $163(90 \%)$ \\
\hline Discontinued ART (by duration) & $61(22 \%)$ & $42(46 \%)$ & $19(10 \%)$ \\
\hline$<1$ month & $32(12 \%)$ & $23(25 \%)$ & $9(5 \%)$ \\
\hline$>1$ month & $29(10 \%)$ & $19(21 \%)$ & $10(5 \%)$ \\
\hline \multicolumn{4}{|l|}{ Missed ART follow-up } \\
\hline Never & $233(85 \%)$ & 70 (77\%) & $163(89.5 \%)$ \\
\hline Sometimes & $32(12 \%)$ & $14(15 \%)$ & $18(10 \%)$ \\
\hline Often & $8(3 \%)$ & $7(8 \%)$ & $1(0.5 \%)$ \\
\hline \multicolumn{4}{|l|}{ Repeated or persistent diarrhea } \\
\hline Yes & $24(9 \%)$ & $16(18 \%)$ & $8(4 \%)$ \\
\hline No & $249(91 \%)$ & 75 (82\%) & $174(96 \%)$ \\
\hline \multicolumn{4}{|l|}{ Psychiatric illness } \\
\hline Yes & $10(4 \%)$ & $6(7 \%)$ & $4(2 \%)$ \\
\hline No & $263(96 \%)$ & 85 (93\%) & $178(98 \%)$ \\
\hline \multicolumn{4}{|l|}{ Dyspepsia } \\
\hline Yes & $82(30 \%)$ & $31(34 \%)$ & $51(28 \%)$ \\
\hline No & $191(70 \%)$ & $60(66 \%)$ & $131(72 \%)$ \\
\hline \multicolumn{4}{|l|}{ Diabetic } \\
\hline Yes & $1(0.4 \%)$ & $1(1 \%)$ & $0(0 \%)$ \\
\hline No & $272(99.6 \%)$ & $90(99 \%)$ & $182(100 \%)$ \\
\hline \multicolumn{4}{|l|}{ Hypertensive } \\
\hline Yes & $3(1 \%)$ & $0(0 \%)$ & $3(2 \%)$ \\
\hline No & $270(99 \%)$ & $91(100 \%)$ & 179 (98\%) \\
\hline \multicolumn{4}{|l|}{ Stool H. pylori antigen positive } \\
\hline Yes & $64(23 \%)$ & $18(20 \%)$ & $46(25 \%)$ \\
\hline No & $209(77 \%)$ & $73(80 \%)$ & $136(75 \%)$ \\
\hline \multicolumn{4}{|l|}{ HBsAg positive } \\
\hline Yes & $12(4 \%)$ & $3(3 \%)$ & $9(5 \%)$ \\
\hline No & $261(96 \%)$ & $88(97 \%)$ & $173(95 \%)$ \\
\hline \multicolumn{4}{|l|}{ Anti-HCV positive } \\
\hline Yes & $5(2 \%)$ & $1(1 \%)$ & $4(2 \%)$ \\
\hline
\end{tabular}


Table 1 Socio-demographic and baseline clinical characteristic of adult HIV-positive patients, Southeast Ethiopia, 2015-2017 (Continued)

\begin{tabular}{llll}
\hline Variables & $\begin{array}{l}\text { Total } \\
(N=273)\end{array}$ & $\begin{array}{l}\text { Patients with ART failure (Cases) } \\
(N=91)\end{array}$ & $\begin{array}{l}\text { Patients without ART failure (Controls) } \\
(N=182)\end{array}$ \\
\hline No & $268(98 \%)$ & $90(99 \%)$ & $174(96 \%)$ \\
VRDL positive & & & $43(24 \%)$ \\
Yes & $56(20 \%)$ & $13(14 \%)$ & $139(76 \%)$ \\
No & $217(80 \%)$ & $78(86 \%)$ & \\
\hline
\end{tabular}

Note: ART: Antiretroviral Therapy; AZT: Azidothymidine (Zidovudine); HCV: Hepatitis C virus; $\mathrm{H}$. pylori: Helicobacter pylori; HBsAg: Hepatitis B surface antigen; IQR: interquartile range; TDF: Tenofovir; TB: tuberculosis; VDRL: Venereal disease research laboratory; WHO: World Health Organization. ${ }^{*}$ Teff (Eragrostis tef) is a glutenfree cereal traditionally grown in Ethiopia [25]. ${ }^{* *}$ Khat (Catha edulis) is a plant native to the Horn of Africa and the Arabian Peninsula which contains psychoactive substances that have a high abuse potential [26]

When we compare the characteristics of cases with controls in terms of age, sex and duration of ART; they were roughly comparable in a 1:2 ratio. Compared with controls, cases were six times more affected with active tuberculosis and four times more likely to have persistent diarrhea (Tables 1 and 2).

\section{Discussion}

This study identified discontinuation of ART, baseline CD4 lymphocyte count $\leq 50$ cells $/ \mathrm{mm}^{3}$ and persistent diarrhea as independent factors for first-line ART failure. The risk of ART failure was high and comparable whether the duration of ART discontinuation was

Table 2 Risk factors for ART failure in adult HIV-positive patients, Southeast Ethiopia, 2015-2017

\begin{tabular}{|c|c|c|c|c|c|c|}
\hline \multirow[t]{2}{*}{ Variables } & \multicolumn{3}{|c|}{ Bivariate analysis } & \multicolumn{3}{|c|}{ Multivariate analysis } \\
\hline & $\mathrm{COR}$ & $95 \% \mathrm{Cl}$ & $\overline{P \text {-value }}$ & $\overline{\mathrm{AOR}}$ & $95 \% \mathrm{Cl}$ & $\overline{\text { P-value }}$ \\
\hline Illiterate & 0.9 & $0.4-1.8$ & 0.714 & & & \\
\hline Small family $\leq 5$ & 1.5 & $0.8-2.8$ & 0.245 & & & \\
\hline Residence in rural area & 1.6 & $0.9-2.9$ & 0.092 & 1.4 & $0.6-2.9$ & 0.396 \\
\hline Unemployed & 4.1 & $0.7-23$ & 0.105 & 1.5 & $0.1-27.2$ & 0.775 \\
\hline Unmarried & 1.5 & $0.9-2.6$ & 0.100 & 1.4 & $0.7-2.7$ & 0.379 \\
\hline Alcohol & 3.1 & $0.4-25.9$ & 0.303 & & & \\
\hline smoking cigarette & 2.0 & $0.4-10.3$ & 0.390 & & & \\
\hline Khat $^{* *}$ chewing & 1.3 & $0.4-4.9$ & 0.650 & & & \\
\hline Main diet wheat or barley vs other food & 1.8 & $0.9-3.5$ & 0.093 & 2.3 & $0.9-5.4$ & 0.064 \\
\hline Main diet teff vs wheat or barley & 0.6 & $0.3-1.2$ & 0.147 & & & \\
\hline Baseline CD4 lymphocyte count $\leq 50$ cells $/ \mathrm{mm}^{3}$ & 3.7 & $1.7-7.8$ & $<0.001$ & 3.8 & $1.5-9.6$ & 0.005 \\
\hline Baseline WHO stage 4 & 3.9 & $1.3-12.0$ & 0.018 & 0.3 & $0.1-1.4$ & 0.138 \\
\hline Discontinuation of ART & 7.4 & $3.9-13.8$ & $<0.001$ & 9.8 & $4.0-23.8$ & $<0.001$ \\
\hline$<1$ month & 8.5 & $3.7-19.6$ & $<0.001$ & & & \\
\hline$>1$ month & 6.3 & $2.8-14.5$ & $<0.001$ & & & \\
\hline AZT based regimen & 1.5 & $0.9-2.5$ & 0.121 & 1.3 & $0.7-2.6$ & 0.392 \\
\hline Missed ART follow-up & 2.6 & $1.3-5.1$ & 0.007 & 1.6 & $0.6-4.8$ & 0.362 \\
\hline Repeated or persistent diarrhea & 4.6 & $1.9-11.3$ & $<0.001$ & 4.4 & $1.5-13.2$ & 0.007 \\
\hline Dyspepsia & 1.3 & $0.8-2.3$ & 0.305 & & & \\
\hline Psychiatric illness & 3.1 & $0.9-11.4$ & 0.082 & 0.6 & $0.3-1.5$ & 0.272 \\
\hline Anti-HCV positive & 2.0 & $0.2-18.4$ & 0.531 & & & \\
\hline HBsAg positive & 1.5 & $0.04-5.8$ & 0.534 & & & \\
\hline H. pylori antigen positive & 0.7 & $0.4-1.3$ & 0.314 & & & \\
\hline VDRL positive & 0.5 & $0.3 \_1.1$ & 0.074 & 0.6 & $0.3-1.5$ & 0.272 \\
\hline
\end{tabular}

Note: ART: Antiretroviral Therapy; AZT: Azidothymidine (Zidovudine); Cl: Confidence interval; COR: Crude odds ratio; HCV: Hepatitis C virus; $H$. pylori: Helicobacter pylori; HBsAg: Hepatitis B surface antigen; VDRL: Venereal disease research laboratory; WHO: World Health Organization. ${ }^{*}$ Teff (Eragrostis tef) is a gluten-free cereal traditionally grown in Ethiopia [25]. ${ }^{* *}$ Khat (Catha edulis) is a plant native to the Horn of Africa and the Arabian Peninsula and contains psychoactive substances that have a high abuse potential [26] 
greater or less than 1 month. Frequent eating of a diet made of wheat or barely showed a trend of statistically significant association with first-line ART failure.

Patients who did experience first-line ART failure were nearly 10 times more likely to have a history of total ART discontinuation (AOR $=9.8,95 \%$ CI: 4.0-23.8) than those who did not. The risk of ART failure in patients who discontinued ART for more than 1 month $(\mathrm{COR}=$ 6.3, 95\% CI: 2.8-14.5) was comparable with those who discontinued it for less than 1 month $(\mathrm{COR}=8.5,95 \%$ CI: 3.7-19.6). The association between ART failure and drug discontinuation was also significant in other studies conducted in a similar setting. Comparable findings were reported by case-control studies from Zimbabwe (AOR = 5.1, 95\% CI 2.8-10.0) [19], Tanzania (AOR $=12.0,95 \%$ CI 2.1-69.3) [27] and the northern part of Ethiopia $(\mathrm{AOR}=15.80,95 \% \mathrm{CI}: 6.9-36.5)$ [28].

Patients who were initiated on ART at an advanced stage of HIV/AIDS (baseline CD4 lymphocyte count $\leq 50$ cells $/ \mathrm{mm}^{3)}$ were four times more likely to experience first-line ART failure (AOR $=3.8,95 \% \mathrm{CI}$ : $1.5-9.6)$ in this study. Several studies reported that starting ART late in patients with advanced immunosuppression is associated with antiretroviral treatment failure [17, 29-33].

Persistent diarrhea was also found to be an independent predictor of ART failure (AOR $=4.4,95 \%$ CI: $1.5-$ 13.2) as documented in other studies [34, 35]. Poor absorption of ART medications associated with a general malabsorption state could occur in patients with persistent diarrhea. However, this finding could be an overestimation as persistent diarrhea could be a manifestation of ART failure itself with disproportionately more diarrheal cases among the cases group.

Furthermore, frequent eating of wheat or barley-based meal $(\mathrm{AOR}=2.3,95 \% \mathrm{CI}: 0.9-5.4)$ showed a trend to be a risk factor for first-line ART failure ( $p$-value $<0.064)$ compared with other food. It is important to note that wheat and barley are gluten-containing foods, and both foods accelerate gastrointestinal transit $[36,37]$. Compared to barley and wheat, frequent eating of teff, which is a gluten-free staple grain of Ethiopian cuisine [25], showed a decreased odds ratio for ART failure (COR $=0.6,95 \%$ CI: $0.3-1.2)$. To our knowledge, there are no previous studies that documented frequent eating of wheat and barley-based diet as a risk factor for first-line ART failure, and further studies with larger sample size are required before generalizing.

Our study has several limitations. Most of the independent variables were self-reported. Therefore, memory bias and imperfect temporal precedence could have under or overestimated our results. The smaller study population and sensitivity and specificity of laboratory tests might also have affected the accuracy of our findings.

\section{Conclusions}

Discontinuation of ART drugs, persistent diarrhea and baseline CD4 lymphocyte count $\leq 50$ cells $/ \mathrm{mm}^{3}$ were strongly associated with first-line ART failure. Our findings underscore the importance of avoiding ART discontinuation of any duration to prevent treatment failure. Wheat or barley as the main diet could be a possible cause for ART failure; however, further studies are needed.

\section{Abbreviations \\ AOR: Adjusted odds ratio; ART: Antiretroviral Therapy; AZT: Azidothymidine (Zidovudine); Cl: Confidence interval; COR: Crude odds ratio; $\mathrm{H}$. pylori: Helicobacter pylori; HBsAg: Hepatitis B virus surface antigen; HBV: Hepatitis B virus; HCV: Hepatitis C virus; HIV: Human Immunodeficiency Virus; mL: milliliter; NNRTI: Non-nucleoside reverse transcriptase inhibitor; SD: Standard deviation; TB: Tuberculosis; VDRL: Venereal disease research laboratory; WHO: World Health Organization}

\section{Publisher's Note}

Springer Nature remains neutral with regard to jurisdictional claims in published maps and institutional affiliations.

\section{Acknowledgements}

The authors would like to thank the entire ART clinic staff at Asella Hospital.

\section{Authors' contributions}

YB took the lead in the study design, proposal writing, data collection, compilation, analysis and drafted the manuscript. FB contributed in the study design, data collection and manuscript writing. WB contributed to study design and manuscript writing. All authors read and approved the final manuscript.

\section{Funding}

This study was funded by Arsi University. The university had no role in study design, data collection and analysis, decision to publish or preparation of the manuscript.

\section{Availability of data and materials}

The datasets generated and/or analyzed during the current study are not publicly available due to the sensitivity of the topic and hence to ensure confidentiality of the information but are available from the corresponding author on reasonable request.

\section{Ethics approval and consent to participate}

Ethics approval obtained from the Arsi University College of Health Sciences Ethics Review Board (A/COHS/R/0010/15/16). All participants provided written informed consent.

\section{Consent for publication}

Not applicable.

\section{Competing interests}

The authors declare that they have no competing interests.

\section{Author details}

${ }^{1}$ College of Health Sciences, Arsi University, Arsi, Ethiopia. ${ }^{2}$ ONIRIS: The Nantes-Atlantic National College of Veterinary Medicine, Nantes, France. ${ }^{3}$ Division of Pharmacy, School of Medicine, University of Tasmania, Tasmania, Australia.

Received: 11 January 2019 Accepted: 5 June 2019

Published online: 18 June 2019

\section{References}

1. WHO. Antiretroviral therapy coverage data and estimates by WHO region 2018 [updated 17 November 2018. Available from: http://apps.who.int/gho/ data/view.main.23300REGION?lang=en. 
2. WHO. Antiretroviral therapy (ART) coverage among all age groups 2018 [17 November 2018]. Available from: https://www.who.int/gho/hiv/epidemic response/ART_text/en/.

3. UNAIDS. Global HIV \& AIDS statistics - 2018 fact sheet 2018 [cited 2018 November 17]. Available from: http://www.unaids.org/en/resources/factsheet.

4. Hamers RL, Sigaloff KC, Kityo C, Mugyenyi P, de Wit TF. Emerging HIV-1 drug resistance after roll-out of antiretroviral therapy in sub-Saharan Africa. Curr Opin HIV AIDS. 2013;8(1):19-26.

5. Alagaw A, Godana W, Taha M, Dejene T. Factors associated with antiretroviral treatment adherence among adult patients in Wolaita Soddo hospital, Wolaita zone, southern Ethiopia. Sci J Public Health. 2014;2:69-77.

6. Renaud-Théry F, Duncombe C, Kerr S, Thierry S, Perriëns J, editors. Adult antiretroviral therapy in resource limited settings: a systematic review of first-line failure and attrition rates. 17th Conference on Retroviruses and Opportunistic Infections; 2010; San Francisco.

7. Kassa D, Gebremichael G, Alemayehu Y, Wolday D, Messele T, van Baarle D. Virologic and immunologic outcome of HAART in human immunodeficiency virus (HIV)-1 infected patients with and without tuberculosis (TB) and latent TB infection (LTBI) in Addis Ababa, Ethiopia. AIDS Res Ther. 2013;10:18.

8. Abdissa A, Yilma D, Fonager J, Audelin AM, Christensen LH, Olsen MF, et al. Drug resistance in HIV patients with virological failure or slow virological response to antiretroviral therapy in Ethiopia. BMC Infect Dis. 2014;14:181.

9. Teshome Yimer Y, Yalew AW. Magnitude and predictors of anti-retroviral treatment (ART) failure in private health facilities in Addis Ababa, Ethiopia. PLoS One. 2015;10(5):e0126026.

10. Tsegaye AT, Wubshet M, Awoke T, Addis Alene K. Predictors of treatment failure on second-line antiretroviral therapy among adults in Northwest Ethiopia: a multicentre retrospective follow-up study. BMJ Open. 2016;6(12): e012537.

11. Deeks SG, Gange SJ, Kitahata MM, Saag MS, Justice AC, Hogg RS, et al. Trends in multidrug treatment failure and subsequent mortality among antiretroviral therapy-experienced patients with HIV infection in North America. Clin Infect Dis. 2009;49(10):1582-90.

12. Onoya D, Hirasen K, van den Berg L, Miot J, Long LC, Fox MP. Adverse drug reactions among patients initiating second-line antiretroviral therapy in South Africa. Drug Saf. 2018:41(12):1343-53.

13. Jerene D. HIV antiretroviral therapy in Ethiopia overcoming implementation challenges. Norway: University of Bergen; 2007.

14. Panel on antiretroviral guidelines for adults and adolescents. Guidelines for the use of antiretroviral agents in adults and adolescents with HIV. Department of Health and Human Services 2018 [cited 201910 May]. Available from: https:/aidsinfo.nih.gov/contentfiles/lvguidelines/ adultandadolescentgl.pdf.

15. Mocroft A, Youle M, Moore A, Sabin CA, Madge S, Lepri AC, et al. Reasons for modification and discontinuation of antiretrovirals: results from a single treatment Centre. AIDS (London, England). 2001;15(2):185-94.

16. Paredes R, Lalama CM, Ribaudo HJ, Schackman BR, Shikuma C, Giguel F, et al. Pre-existing minority drug-resistant HIV-1 variants, adherence, and risk of antiretroviral treatment failure. J Infect Dis. 2010;201(5):662-71.

17. Kwobah CM, Mwangi AW, Koech JK, Simiyu GN, Siika AM. Factors associated with first-line antiretroviral therapy failure amongst HIV-infected African patients: a case-control study. World Journal of AIDS. 2012;2(4):271-8.

18. Assefa A, Gelaw B, Getnet G, Yitayew G. The effect of incident tuberculosis on immunological response of HIV patients on highly active anti-retroviral therapy at the University of Gondar Hospital, Northwest Ethiopia: a retrospective follow-up study. BMC Infect Dis. 2014;14:468.

19. Matare T, Shambira G, Gombe N, Tshimanga M, Bangure D. Factors associated with human immunodeficiency virus first-line treatment failure in Zvishavane District, Zimbabwe, 2014. Austin Journal of HIV/AIDS Research. 2015;2(1):1010.

20. Babo YD, Alemie GA, Fentaye FW. Predictors of first-line antiretroviral therapy failure amongst HIV-infected adult clients at Woldia hospital, Northeast Ethiopia. PLoS One. 2017;12(11):e0187694.

21. Lenjisa JL, Wega SS, Lema TB, Ayana GA. Outcomes of highly active antiretroviral therapy and its predictors: a cohort study focusing on tuberculosis co-infection in Southwest Ethiopia. BMC research notes. 2015:8:446.

22. Telele NF, Kalu AW, Marrone G, Gebre-Selassie S, Fekade D, Tegbaru B, et al. Baseline predictors of antiretroviral treatment failure and lost to follow up in a multicenter countrywide HIV-1 cohort study in Ethiopia. PLoS One. 2018; 13(7):e0200505.

23. Joram SL, Paul G, Moses K, Stanley B, Isaac M, Allan G, et al. Misdiagnosis of HIV treatment failure based on clinical and immunological criteria in eastern and Central Kenya. BMC Infect Dis. 2017;17(1):383.

24. Sheehan DV, Lecrubier $Y$, Sheehan KH, Amorim P, Janavs J, Weiller E, et al. The MINI-international neuropsychiatric interview (MINI): the development and validation of a structured diagnostic psychiatric interview for DSM-IV and ICD-10. The Journal of clinical psychiatry. 1998.

25. Spaenij-Dekking L, Kooy-Winkelaar Y, Koning F. The Ethiopian cereal tef in celiac disease. N Engl J Med. 2005:353(16):1748-9.

26. WHO Expert Committee on Drug Dependence. Pre-review of psychoactive substances WHO; 2003 [cited 201910 May]. Thirty-third:[Available from: http://apps.who.int/medicinedocs/en/d/Js4896e/.

27. Kapesa A, Magesa D, William A, Kaswija J, Seni J, Makwaya C. Determinants of immunological failure among clients on the first line treatment with highly active antiretroviral drugs in Dar Es Salaam, Tanzania. Asian Pac J Trop Biomed. 2014;4:S620-S4.

28. Bayu B, Tariku A, Bulti AB, Habitu YA, Derso T, Teshome DF. Determinants of virological failure among patients on highly active antiretroviral therapy in University of Gondar Referral Hospital, Northwest Ethiopia: a case-control study. HIV/AIDS (Auckland, NZ). 2017:9:153-9.

29. Rambaut A, Posada D, Crandall KA, Holmes EC. The causes and consequences of HIV evolution. Nat Rev Genet. 2004:5(1):52-61.

30. Khienprasit N, Chaiwarith R, Sirisanthana T, Supparatpinyo K. Incidence and risk factors of antiretroviral treatment failure in treatment-naive HIV-infected patients at Chiang Mai University Hospital, Thailand. AIDS Res Ther. 2011; 8(1):42.

31. Yassin S, Gebretekle GB. Magnitude and predictors of antiretroviral treatment failure among HIV-infected children in fiche and Kuyu hospitals, Oromia region, Ethiopia: a retrospective cohort study. Pharmacol Res Perspect. 2017:5(1).

32. Fox MP, Cutsem GV, Giddy J, Maskew M, Keiser O, Prozesky H, et al. Rates and predictors of failure of first-line antiretroviral therapy and switch to second-line ART in South Africa. J Acquir Immune Defic Syndr. 2012;60(4): 428-37.

33. Robbins GK, Daniels B, Zheng $H$, Chueh $H$, Meigs JB, Freedberg KA Predictors of antiretroviral treatment failure in an urban HIV clinic. J Acquir Immune Defic Syndr. 2007:44(1):30-7.

34. Bacha T, Tilahun B, Worku A. Predictors of treatment failure and time to detection and switching in HIV-infected Ethiopian children receiving first line anti-retroviral therapy. BMC Infect Dis. 2012;12:197.

35. Sadashiv MS, Rupali P, Manesh A, Kannangai R, Abraham OC, Pulimood SA, et al. Risk factors of clinical and immunological failure in south Indian cohort on generic antiretroviral therapy. J Assoc Physicians India. 2017; 65(12):34-9.

36. Lupton JR, Morin JL, Robinson MC. Barley bran flour accelerates gastrointestinal transit time. J Am Diet Assoc. 1993;93(8):881-5.

37. Payler DK, Pomare EW, Heaton KW, Harvey RF. The effect of wheat bran on intestinal transit. Gut. 1975:16(3):209-13.

Ready to submit your research? Choose BMC and benefit from

- fast, convenient online submission

- thorough peer review by experienced researchers in your field

- rapid publication on acceptance

- support for research data, including large and complex data types

- gold Open Access which fosters wider collaboration and increased citations

- maximum visibility for your research: over $100 \mathrm{M}$ website views per year

At BMC, research is always in progress.

Learn more biomedcentral.com/submissions 